\title{
Description of the stylohyal bone of a giant sloth (Lestodon armatus)
}

\author{
P. Sebastián Tambusso, H. Gregory McDonald, and Richard A. Fariña
}

\begin{abstract}
The hyoid apparatus in fossil Xenarthrans is rarely preserved. Its largest bone, the stylohyal, is the most frequently found as an isolated element. It is known for some species of Pleistocene ground sloths (Megalonyx jeffersonii, Megatherium americanum, Paramylodon harlani, Nothrotheriops shastensis, Glossotherium robustum and Scelidotherium leptocephalum) but not for the largest mylodontid Lestodon armatus. Here we describe a right stylohyal found in the late Pleistocene megafaunal bonebed of the Arroyo del Vizcaíno site, Uruguay, as two perfectly matched pieces that were within a few centimeters of each other. A small notch, possibly a conchoidal flaked perimortem fracture, is observed in the lateral face. The specimen, whose general form is a sinusoid cylinder with the proximal end expanded and compressed, must have belonged to a juvenile individual, since it lacks both the distal and proximal surfaces that articulate with the skull and the epihyal, respectively. Instead, both ends show an irregular surface as those seen in the contact with the growth cartilage. Additionally, its maximum length is $105 \mathrm{~mm}$, larger than the equivalent part of the stylohyal of adult Glossotherium. At the expanded proximal end that articulates with the skull the large fossa found in Glossotherium and Scelidotherium cannot be observed, which could be due to a taxonomic difference, to the stage of growth or both of them. The bone shows marks, several interpreted as caused by trampling and at least one with features as those left by human tools.
\end{abstract}

P. Sebastián Tambusso. Sección Paleontología, Facultad de Ciencias, Universidad de la República, Iguá 4225, 11400 Montevideo, Uruguay pasebita@gmail.com

H. Gregory McDonald. Museum Management Program, National Park Service, 1201 Oakridge Drive, Fort Collins, Colorado 80521 USA greg_mcdonald@nps.gov

Richard A. Fariña. Sección Paleontología, Facultad de Ciencias, Universidad de la República, Iguá 4225, 11400 Montevideo, Uruguay dogor@netgate.com.uy

Keywords: ground sloth; stylohyal;, three-dimensional reconstruction; Pleistocene

PE Article Number: 18.1.19A

Copyright: Society for Vertebrate Paleontology April 2015

Submission: 13 August 2014. Acceptance: 12 March 2015

Tambusso, P. Sebastián, McDonald, H. Gregory, and Fariña, Richard A. 2015. Description of the stylohyal bone of a giant sloth (Lestodon armatus). Palaeontologia Electronica 18.1.19A: 1-10.

palaeo-electronica.org/content/2015/1119-stylohyal-of-a-giant-sloth 


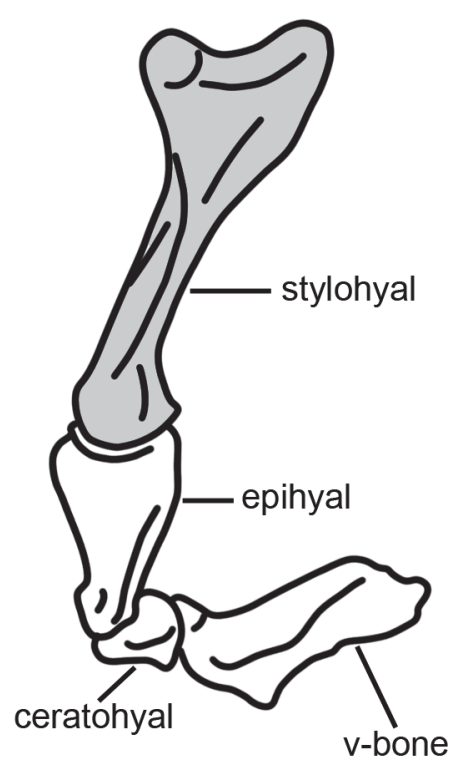

FIGURE 1. Left hyoid apparatus of the ground sloth Paramylodon harlani (modified from Stock, 1925). Shaded in grey is the fossil specimen analyzed in this work.

\section{INTRODUCTION}

Several aspects of the paleobiology of the South American megafauna (Fariña et al., 2013) have been studied in the past decades. One of them is the analysis of the remarkably fused hyoid apparatus of fossil Xenarthrans (Pérez et al., 2010), which provides insight on the form of the tongue and its function in food intake and intraoral processing.

The hyoid apparatus of mammals is generally formed by four paired bones (stylohyals, epihyals, ceratohyals and thyrohyals) and the unpaired basihyal. In xenarthrans (Figure 1), the thyrohyals and basihyal are fused and form a basithyrohyal or Vbone (Pérez et al., 2010); in Pleistocene glyptodonts the epihyal, ceratohyal and stylohyal are fused and form the sigmohyal bone (Pérez et al., 2000). Among Pleistocene ground sloths, the morphofunctional analyses of Perez et al. (2010) indicate a high capacity for tongue protusion in mylodontines and a more limited capacity in Scelidotherium and Megatherium.

Preservation of the complete hyoid apparatus for most fossil sloth taxa is rare, and commonly only isolated elements, commonly the stylohyal, are known. Leidy (1855) illustrated the fused basithyrohyal in Megalonyx jeffersonii. Stock (1925) described and illustrated the complete hyoid of the North American mylodont, Paramylodon har- lani, based on a composite of isolated bones recovered from the tar pits at Rancho La Brea, California, and referred a single stylohyal and basithyrohyal from the same locality to the nothrothere, Nothrotheriops shastensis. Pérez et al. (2010) described the hyoid bones for several fossil Xenarthran species, including the mylodontid ground sloths Glossotherium robustum and Scelidotherium leptocephalum, but did not include any specimens referred to the largest mylodont Lestodon armatus. In this paper we describe a right stylohyal (Figure 2 ), which we refer to the large mylodontid Lestodon armatus, found in the late Pleistocene megafaunal bonebed of the Arroyo del Vizcaíno site near the town of Sauce, Departamento de Canelones, Uruguay, dated between 27 and 32 ky (Fariña et al., 2014). The stylohyal is the upper most proximal element of the anterior cornua that articulates with the petrous part of the temporal in the basicranium, via the tympanohyal ligament or cartilage. We should note our orientation of elements starts at the skull making the stylohyal the most proximal element while Naples (1986) started at the basihyal and considered the stylohyal the most distal element in the series.

Although Glossotherium is also present in the fauna from the Arroyo del Vizcaíno, because Lestodon is the most commonly found species in that site, we feel confident in referring the described specimen to this genus for the reasons to be discussed below.

\section{Acronyms}

CAV: Colección Arroyo del Vizcaíno, Sauce, Uruguay; MNHN: Museo de Historia Natural, Montevideo, Uruguay; MLP: Museo de La Plata, La Plata, Argentina; MNHN PAM: Muséum National d'histoire Naturelle, Paris, France.

\section{BONE DESCRIPTION}

The stylohyal (CAV 476) was found in two pieces that were within a few centimeters of each other. They were put together and a perfect match was observed (Figures 2, 3), leaving only a small notch in the medial face and a larger one in the lateral face, which is interpreted as a conchoidal flaked oblique (hence perimortem) fracture like those caused by an impact when the bone was still fresh (Fisher, 1995; Pickering et al., 2005).

Three-dimensional (3D) reconstructions of the stylohyal CAV 476 and a sthylohyal of Glossotherium robustum (MNHN 914) were performed with DAVID SLS-2 structured light scanning (Figures 3, 4). The $3 D$ reconstructions have the advantage 
1

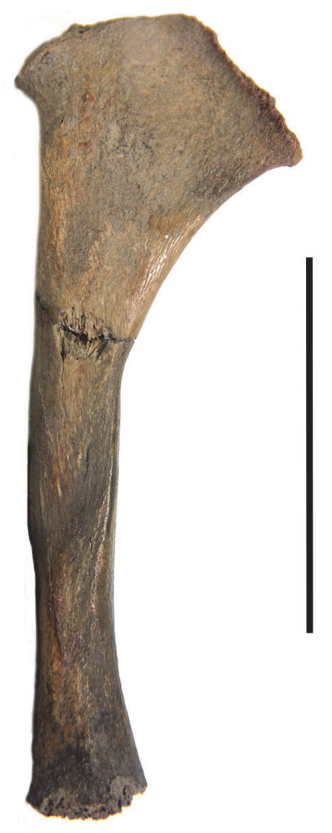

\section{2

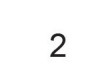

2
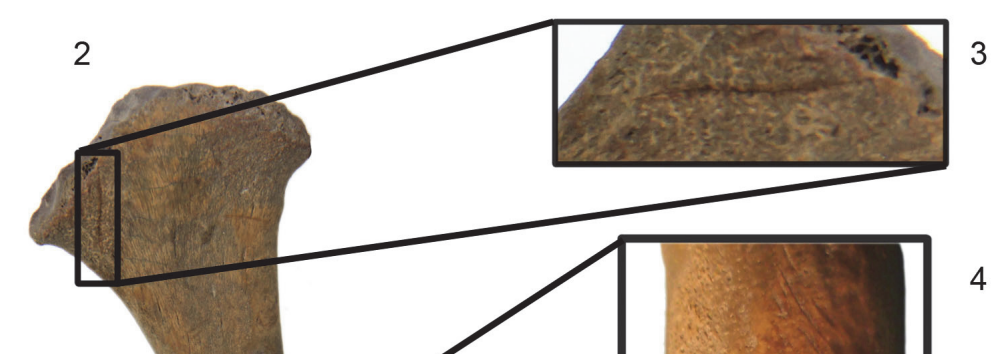

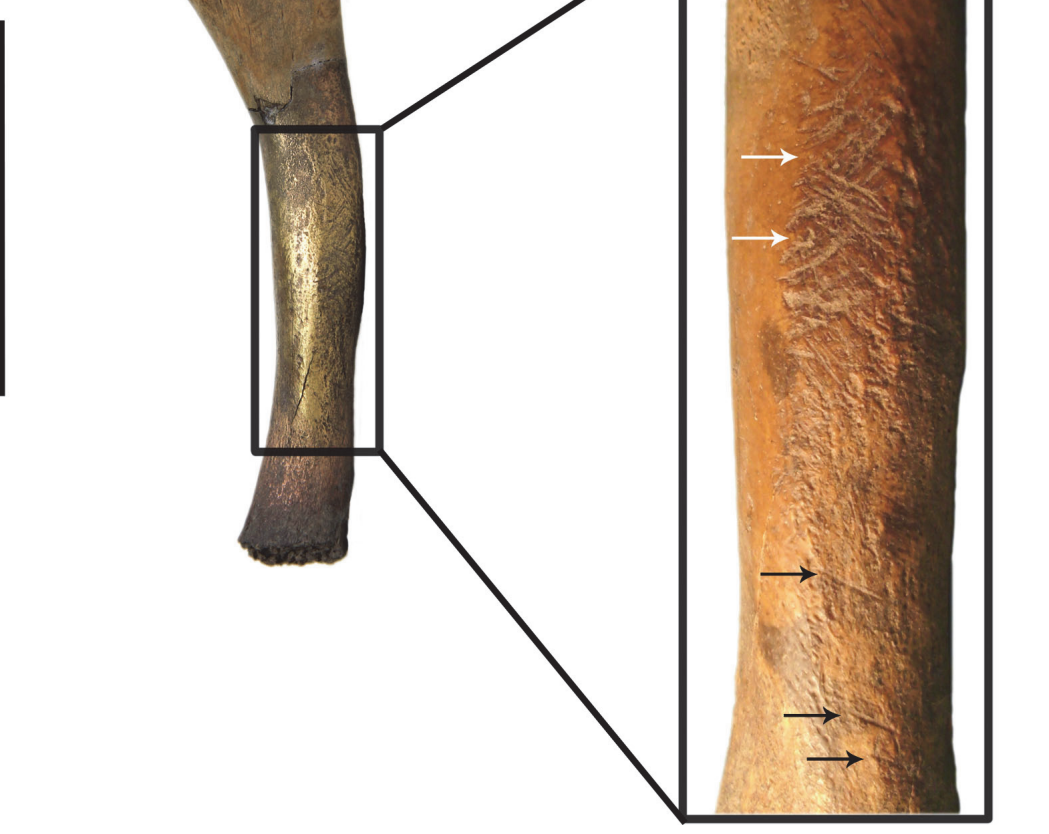

FIGURE 2. Juvenile stylohyal (CAV 476) in 1, medial view; 2, lateral view. The glittering of the cylindrical part is due to its having been bathed in gold for SEM observations; 3, close up of the cut mark analyzed by Fariña et al (2014); 4, close up of the marks in the midshaft. White arrows indicate probable trampling marks; black arrows indicate probable cut marks. Scale bar equals $50 \mathrm{~mm}$.

that they can be manipulated (rotated, enlarged and measured) by the reader in order to visualize and compare the structures pointed in the text.

As mentioned before, the hyoid apparatus in xenarthrans is distinguished from other mammals by the co-ossification of some elements such as the basihyal and thyrohyal bones, although most fossil sloths retain independent elements, including the stylohyal (Pérez et al., 2010). Like in most mammals, in sloths the stylohyal is the largest bone in the hyoid series and is commonly preserved. The form of the bone from the Arroyo del Vizcaíno site is similar to that of other sloths (Figure 5), both extinct (Pérez et al., 2010) and extant (Naples, 1986). Its form is of a sinusoid cylinder with the proximal end expanded and mediolaterally compressed for the origin of the styloglossus muscle (Naples, 1986). The specimen lacks the surfaces that articulate proximally with the skull, at the tympanohyal, and distally with the epihyal. Instead, both ends show an irregular surface commonly seen in the diaphyses of juvenile individuals since the epiphyseal closure in most mammals occurs relatively late in the ontogeny. Its maximum length is $105 \mathrm{~mm}$, its anteroposterior diameter at midshaft is $10 \mathrm{~mm}$, and its mediolateral diameter is $9 \mathrm{~mm}$. The maximum anteroposterior dimension of the expanded proximal end is $38 \mathrm{~mm}$. The general shape is more sinusoidal than in Glossotherium, maybe due to a large mediolateral constriction in the midshaft. At the expanded end that articulates with the skull there is a large fossa in Glossotherium (Figure 4) and in Scelidotherium (Pérez et al., 2010 , figure 6), while in the Lestodon this fossa is not apparent. Since we could not find a stylohyal of an adult Lestodon to compare, it is not possible to rule it out that this is a taxonomic difference, simply reflects the stage of growth or a combination of both. 


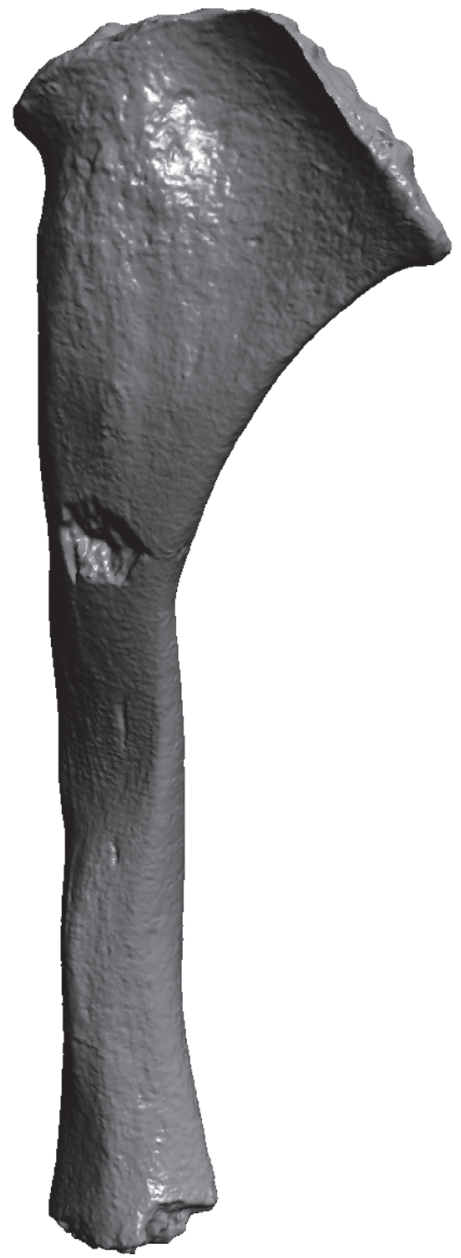

FIGURE 3. Three-dimensional reconstruction of the juvenile ground sloth stylohyal (CAV 476). Medial view (3D object see online Appendix 2 for animated PDF. palaeo-electronica.org/content/2015/1119-stylohyal-of-agiant-sloth).

\section{Marks}

Thirteen parallel marks are observed in the midshaft, which are likely to have been caused by trampling and one at the proximal end (Figures 2.3, 3 ). The latter shows features of those caused by human agency, seen on other bones of Lestodon from the site, as discussed in Fariña et al. (2014). That mark on the stylohyal was studied using an Olympus SZ61 stereomicroscope under a magnification of $45 x$ and methods based on extended depth-of-field to analyze several features of the mark. The depth of the cut is $0.151 \mathrm{~mm}$ with an opening angle of $124^{\circ}$. The presence of asymmetrical shoulders, along with the depth and angle of the cut, resemble the features found in fossil bones

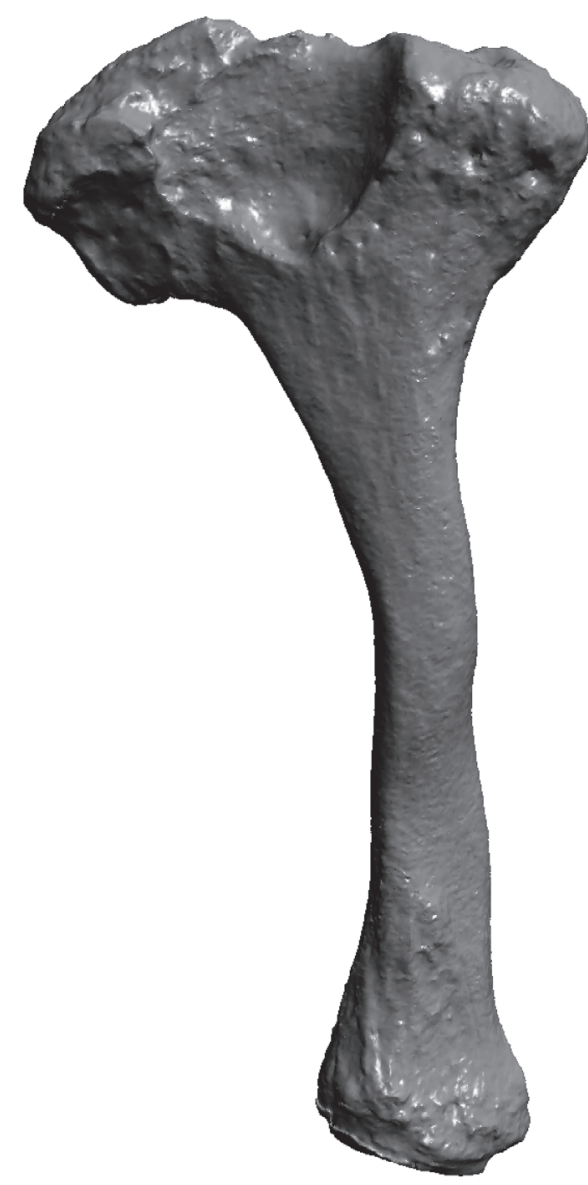

FIGURE 4. Three-dimensional reconstruction of the stylo hyal of adult Glossotherium (MNHN 914). Medial viev (3D object see online Appendix 2 for animated PDF. pal aeo-electronica.org/content/2015/1119-stylohyal-of-agiant-sloth).

cut with flint tools (Bello et al., 2009). The mark examined is located in the proximal end of the stylohyal, close to the area of insertion of the muscle styloglossus of Naples (1986), or occipitohyoideus of Pérez et al. (2010) (Figure 2.2)

\section{DISCUSSION}

\section{A Juvenile Lestodon?}

As noted, the total length of the element studied is $105 \mathrm{~mm}$. The stylohyal of adult Glossotherium robustum (MNHN 914) measured had a total length of $125 \mathrm{~mm}$, and the equivalent part measures about $94 \mathrm{~mm}$ (Figure 4). The stylohyal of $\mathrm{G}$. robustum in Pérez et al. (2010, figure 6), had equivalent measurements. Stock (1925) reported an average length of $129.3 \mathrm{~mm}$ based on 20 right 
1

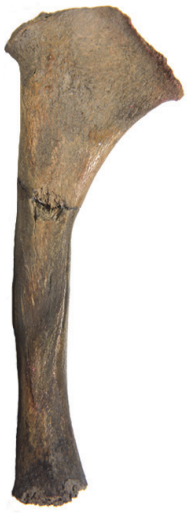

2

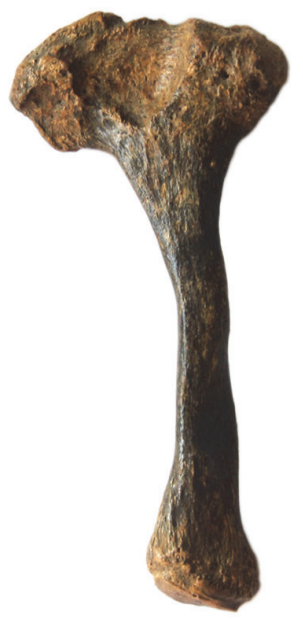

3

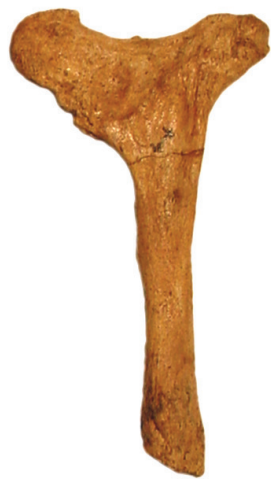

4

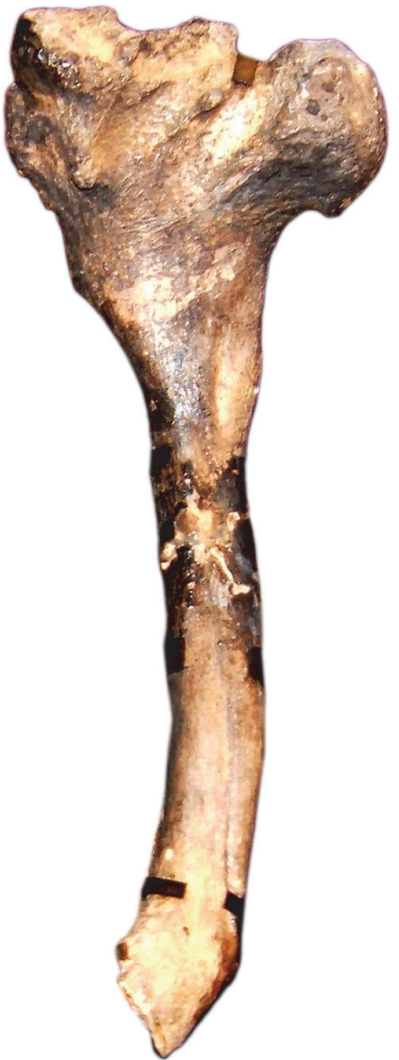

FIGURE 5. Stylohyals of 1, juvenile ground sloth (CAV 476); 2, adult Glossotherium (MNHN 914); 3, adult Scelidotherium.(MLP 3-671); 4, Adult Megatherium (MNHN PAM 297). Scale bar equals $50 \mathrm{~mm}$.

stylohyals of Paramylodon harlani. If geometric similarity is assumed between these two morphologically similar and closely related ground sloths (see Fariña et al., 1998 for discussion on body mass), an adult Lestodon armatus must have had a stylohyal of about $125 \mathrm{~mm} \times(4000 \mathrm{~kg} / 1500 \mathrm{~kg})^{1 / 3}$ $=173 \mathrm{~mm}$ in length. This difference in size, along with the fact that both ends show the usual morphology of the attachment to cartilaginous areas (Figure 2, Figure 3), leads us to conclude that the individual was a juvenile specimen of $L$. armatus, whose body mass must have been $1500 \mathrm{~kg}$ x (105 $\mathrm{mm} / 94 \mathrm{~mm})^{3} \approx 2090 \mathrm{~kg}$, again proportionally estimated after G. robustum. However, this must be considered a maximum, since juveniles have allometrically larger heads (Gould, 1966).

A minimum of 20 individuals of $L$. armatus are currently known from the Arroyo del Vizcaíno site including at least three juveniles. Even though this hyoid and other bones cannot be confidently assigned to the same individual, the size of the femur CAV 935 is within the range that would be expected if it did belong to a nearly two-tonne juvenile (Figure 6).

\section{Marks}

The interpretation for the presence of cut marks on the proximal surface of the stylohyal is congruent with the access to the insertion area of the tongue muscle styloglossus by humans. The tongue of this two-tonne individual of Lestodon, if proportional with that of a cow must have had a mass of about $10 \mathrm{~kg}$. According to the chronicles (Concolorcorvo, 1773:33-34, see Appendix), when the wild cattle in that region were hunted for their hides in the eighteenth and nineteenth centuries, the gauchos (or gauderios, former inhabitants of southern South America countryside-equivalent to North American cowboys), preferred to eat meat that was easy to extract, like the subcutaneous muscle in the abdomen (very conveniently called still today "matambre", a corruption from "mata hambre" - literally, hunger killer) and the fat-rich tongue. 


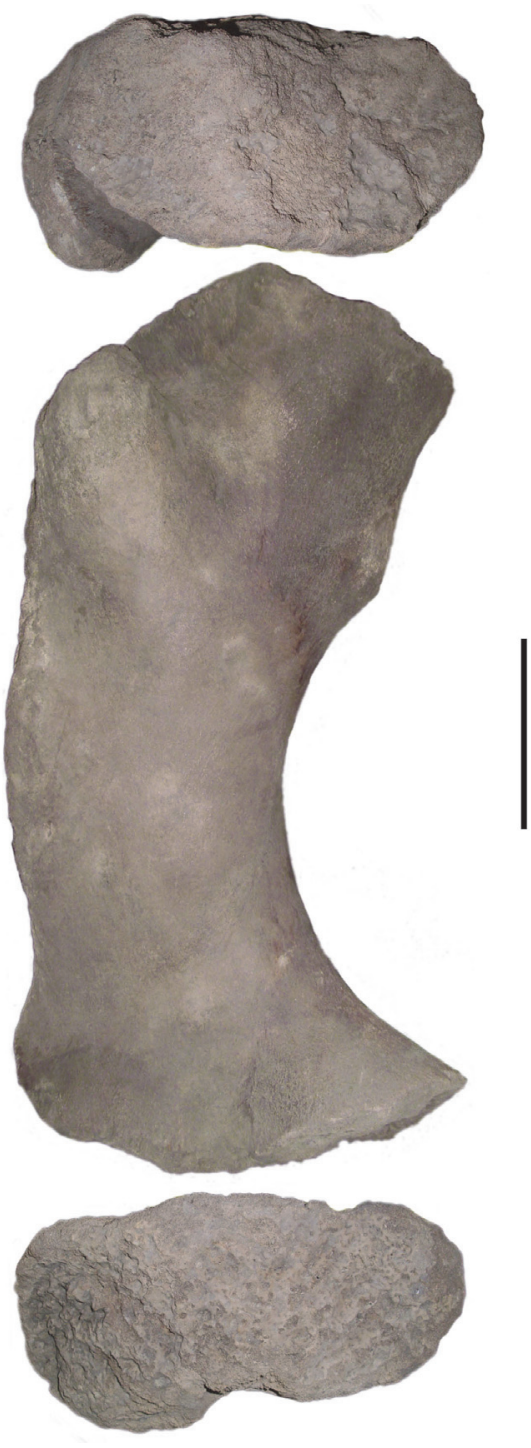

FIGURE 6. Left

femur of juvenile Lestodon (CAV 935) in posterior view showing the proximal (top) and distal (bottom) irregular surfaces of the diaphysis. Scale bar equals $100 \mathrm{~mm}$.

\section{CONCLUSIONS}

We propose that the hyoid described here must have belonged to a sub-adult individual of Lestodon armatus. It shows features compatible with human-made modifications, such as cut marks and a conchoidal fracture. A possible interpretation is that those modifications were produced by humans trying to access the tongue to use it as food.

\section{ACKNOWLEDGMENTS}

Thanks to two anonymous reviewers for the comments and corrections that greatly improve the final manuscript. We are very grateful to $M$. Batallés for the photographs in Figure 2, to M.S. Bargo for photograph of Scelidotherium in Figure 5 and to L.M. Pérez for photograph of Megatherium in Figure 5. Comisión Sectorial de Investigación Científica (CSIC) of the Universidad de la República partially supported this research.

\section{REFERENCES}

Bello, S.M., Parfitt, S.A., and Stringer, C. 2009. Quantitative micromorphological analyses of cut marks produced by ancient and modern handaxes. Journal of Archaeological Science, 36:1869-1880.

Concolorcorvo (Calixto Bustamante Carlos). 1773. El Lazarillo de Ciegos Caminantes. Imprenta de La Rovada, Gijón.

Fariña, R.A., Vizcaíno, S.F., and Bargo, M.S. 1998. Body mass estimations in Lujanian (late Pleistocene-early Holocene of South America) mammal megafauna. Mastozoología Neotropical, 5:87-108.

Fariña, R.A., Vizcaíno, S.F., and De luliis, G. 2013. Megafauna: Giant Beasts of Pleistocene South America. Indiana University Press, Bloomington.

Fariña, R.A., Tambusso, P.S., Varela, L., Czerwonogora, A., Di Giacomo, M., Musso, M., Bracco-Boksar, R., and Gascue, A. 2014. Arroyo del Vizcaíno, Uruguay: A fossil-rich 30-ka-old megafaunal locality with cutmarked bones. Proceedings of the Royal Society B, 281(1774):20132211.

Fisher, J.W. 1995. Bone Surface Modifications in Zooarchaeology. Journal of Archaeological Method and Theory, 2:7-68.

Gould, S.J. 1966. Allometry and size in ontogeny and phylogeny. Biological Review, 41:587-640.

Leidy, J. 1855. A memoir on the extinct sloth tribe of North America. Smithsonian Contributions to Knowledge, 7:1-68.

Naples, V.L. 1986. The morphology and function of the hyoid region in the tree sloths, Bradypus and Choloepus. Journal of Mammalogy, 67:712-724.

Pérez, L.M., Scillato-Yané, G.J., and Vizcaíno, S.F. 2000. Estudio morfofuncional del aparato hioideo de Glyptodon cf. clavipes Owen (Cingulata: Glyptodontidae). Ameghiniana, 37:293-299.

Pérez, L.M., Toledo, N., De luliis, G., Bargo, M.S., and Vizcaíno, S.F. 2010. Morphology and Function of the Hyoid Apparatus of Fossil Xenarthrans (Mammalia). Journal of Morphology, 271:1119-1133.

Pickering, T.R., Domínguez-Rodrigo, M., Egeland, C.P., and Brain, C.K. 2005. The contribution of limb bone fracture patterns to reconstructing early hominid behaviour at Swartkrans Cave (South Africa): Archaeological application of a new analytical method. International Journal of Osteoarchaeology, 15:247-260. 
Stock, C. 1925. Cenozoic gravigrade edentates of Western North America with special references to the Pleistocene Megalonychidae and Mylodontidae of Rancho La Brea. Carniegie Institution of Washington, 331:1-206. 


\section{APPENDIX 1}

Text of Concolorcorvo (1773): Gauderios - also in English.

Estos son unos mozos nacidos en Montevideo y en los vecinos pagos. Mala camisa y peor vestido, procuran encubrir con uno o dos ponchos, de que hacen cama con los sudaderos del caballo, sirviéndoles de almohada la silla. Se hacen de una guitarrita, que aprenden a tocar muy mal y a cantar desentonadamente varias coplas, que estropean, y muchas que sacan de su cabeza, que regularmente ruedan sobre amores. Se pasean a su albedrío por toda la campaña y con notable complacencia de aquellos semibárbaros colonos, comen a su costa y pasan las semanas enteras tendidos sobre un cuero, cantando y tocando. Si pierden el caballo o se lo roban, les dan otro o lo toman de la campaña enlazándolo con un cabestro muy largo que llaman rosario. También cargan otro, con dos bolas en los extremos, del tamaño de las regulares con que se juega a los trucos, que muchas veces son de piedra que forran de cuero, para que el caballo se enrede en ellas, como asimismo en otras que llaman ramales, porque se componen de tres bolas, con que muchas veces lastiman los caballos, que no quedan de servicio, estimando este servicio en nada, así ellos como los dueños.

Muchas veces se juntan de éstos cuatro o cinco, y a veces más, con pretexto de ir al campo a divertirse, no llevando más prevención para su mantenimiento que el lazo, las bolas y un cuchillo. Se convienen un día para comer la picana de una vaca o novillo: le enlazan, derriban y bien trincado de pies y manos le sacan, casi vivo, toda la rabadiIla con su cuero, y haciéndole unas picaduras por el lado de la carne, la asan mal, y medio cruda se la comen, sin más aderezo que un poco de sal, si la llevan por contingencia. Otras veces matan sólo una vaca o novillo por comer el matambre, que es la carne que tiene la res entre las costillas y el pellejo. Otras veces matan solamente por comer una lengua, que asan en el rescoldo. Otras se les antojan caracuces, que son los huesos que tienen tuétano, que revuelven con un palito, y se alimentan de aquella admirable sustancia; pero lo más prodigioso es verlos matar una vaca, sacarle el mondongo y todo el sebo que juntan en el vientre, y con sólo una brasa de fuego o un trozo de estiércol seco de las vacas, prenden fuego a aquel sebo, y luego que empieza a arder y comunicarse a la carne gorda y huesos, forma una extraordinaria iluminación, y así vuelven a unir el vientre de la vaca, dejando que respire el fuego por la boca y orificio, dejándola toda una noche o una considerable parte del día, para que se ase bien, y a la mañana o tarde la rodean los gauderios y con sus cuchillos va sacando cada uno el trozo que le conviene, sin pan ni otro aderezo alguno, y luego que satisfacen su apetito abandonan el resto, a excepción de uno u otro, que lleva un trozo a su campestre cortejo.

Venga ahora a espantarnos el gacetero de Londres con los trozos de vaca que se ponen en aquella capital en las mesas de estado. Si allí el mayor es de a 200 libras, de que comen doscientos milords, aquí se pone de a 500 sólo para siete $\mathrm{u}$ ocho gauderios, que una u otra vez convidan al dueño de la vaca o novillo, y se da por bien servido.

Text of Concolorcorvo (the original Spanish was written in 1773 and this is a loose modernization in terms of the English):

\section{Gauderios}

These are boys born in Montevideo and the neighboring regions. They wear a bad shirt and worse dress, covered up with one or two ponchos. Their bed is made with the saddle pads, and serves them as a chair or pillow. They get a small guitar that they play badly and sing out of tune (so spoiling them) several songs dealing regularly with love. They wander at will throughout the country and with remarkable complacency from those semi-barbarous settlers, eat at their expense and spend entire weeks lying on a hide, singing and playing the guitar. If their horse is lost or stolen, they will get another from the countryside by lassoing it with a long halter that they call a rosary. They also carry another lasso with two balls on the ends, the size of the regular ones that are used to play games, which are often made of stone and lined with leather, so the horse becomes entangled in them, as well as in other called 'branches', com- 
posed of three balls, which often hurts the horses that become useless, estimating this service as nothing, as much as their owners.

Many times they come together in groups of four or five, and sometimes more, under the pretext of going to the field to have fun, carrying with them no more for their maintenance than the lasso, the balls and a knife. They will spend a day eating the rump cap of a cow or bullock: it is lassoed, brought down and well-lashed from the feet and hands they removed, while the animal is almost alive, the whole rump with its skin, they also remove a few carvings of meat from the side, they barely roast it and eat it undercooked, with no more dressing than a little of salt, if they brought any by chance. Sometimes they only kill a cow or bullock to eat the matambre, which is the meat between the ribs and the skin. Sometimes they kill only to eat a tongue that they roast on the embers. Other times they crave caracuces, which are the bones that have marrow, that they stir with a stick, and then feed on that admirable substance; but most prodigious is to see them kill a cow, get the guts and all the tallow that collects in the belly, and with only an ember of fire or a piece of dried cow dung, set fire to that tallow, which then begins to burn and spreads to the fat flesh and bones, forming an extraordinary lighting, and so rejoins the belly of the cow, which breathes fire by the mouth and the hole, leaving it overnight or a substantial part of the day to roast well, and in the morning or afternoon the gauderios surround it and with his knives take out the piece that want, without bread or any other dressing, and then when they have satisfied their appetite they leave the rest, except for one or another, that carry a piece to his countryside entourage.

Come now to frighten us the journalists of London with the chunks of beef that are put in that capital on the tables of state. The largest is 200 pounds, serving two hundred milords, here it becomes 500 for only seven or eight gauderios, who at one time or another invite the owner of the cow or bullock, who then considers himself well served. 
TAMBUSSO, McDONALD, \& FARIÑA: STYLOHYAL OF A GIANT SLOTH

\section{APPENDIX 2}

PDF animations of Figure 3 and 4 - available only online.

palaeo-electronica.org/content/2015/1119-stylohyal-of-a-giant-sloth 